\title{
28 Research Square \\ Selective Etching of Silicon Nitride Over Silicon Oxide using ClF3/H2 Remote Plasma
}

\section{Won Oh Lee}

Sungkyunkwan University

Ki Hyun Kim

Sungkyunkwan University

Doo San Kim

Sungkyunkwan University

You Jin Ji

Sungkyunkwan University

Ji Eun Kang

Sungkyunkwan University

Hyun Woo Tak

Sungkyunkwan University

Jin Woo Park

Sungkyunkwan University

Han Duck Song

Wonik Materials

Ki Seok Kim

Massachusetts Institute of Technology

Byeong Ok Cho

Wonik Materials

Young Lae Kim

Wonik Materials

Geun Young Yeom ( $\sim$ gyyeom@skku.edu )

Sungkyunkwan University

\section{Research Article}

Keywords: silicon nitride (SiNx), silicon oxide (SiOy), chlorine trifluoride (CIF3), selective etching, chemical etching, remote plasma etching, 3D NAND

Posted Date: December 20th, 2021

DOI: https://doi.org/10.21203/rs.3.rs-1148631/v1 
License: (c) (i) This work is licensed under a Creative Commons Attribution 4.0 International License. Read Full License

Version of Record: A version of this preprint was published at Scientific Reports on April 5th, 2022. See the published version at https://doi.org/10.1038/s41598-022-09252-3. 


\section{Abstract}

Precise and selective removal of silicon nitride in a $\mathrm{SiN}_{\mathrm{x}} / \mathrm{SiO}_{\mathrm{y}}$ stack is crucial for a current 3D-NAND (not and) fabrication process. In this study, fast and ultra-high selective isotropic etching of $\mathrm{SiN}_{\mathrm{x}}$ have been studied using a $\mathrm{ClF}_{3} / \mathrm{H}_{2}$ remote plasma in an inductively coupled plasma system and a mechanism of $\mathrm{SiN}_{\mathrm{x}}$ etching was investigated by focusing on the role of $\mathrm{Cl}, \mathrm{F}$, and $\mathrm{H}$ radicals in the plasma. The $\mathrm{SiN}_{\mathrm{x}}$ etch rate over $800 \AA /$ min with the etch selectivity of $\sim 130$ could be observed under a $\mathrm{ClF}_{3}$ remote plasma at a room temperature. Furthermore, compromising the etch rate of $\mathrm{SiN}_{\mathrm{x}}$ by adding $\mathrm{H}_{2}$ to the $\mathrm{ClF}_{3}$ plasma, the etch selectivity of $\mathrm{SiN}_{\mathrm{x}}$ over $\mathrm{SiO}_{\mathrm{y}}$ close to $\sim 200$ could be obtained. The etch characteristics of $\mathrm{SiN}_{\mathrm{x}}$ and $\mathrm{SiO}_{y}$ with increasing the process temperature demonstrated the higher activation energy of $\mathrm{SiO}_{\mathrm{y}}$ compared to that of $\mathrm{SiN}_{\mathrm{x}}$ with $\mathrm{ClF}_{3}$ plasma.

\section{Introduction}

As the semiconductor device size is decreased to sub-nanoscale and the device integration is changed from two dimensional to three dimensional structure, more precise and selective process technology is required for the semiconductor device fabrication[1]. In the various semiconductor devices, silicon nitride has been widely used as a barrier layer for dopant diffusion, a gate sidewall spacer layer, a buffer layer, etc. due to high insulating characteristics, high thermal and mechanical stability, etc. and selective etching of silicon nitride over silicon and/or silicon oxide is important for various microelectronic applications[2].

These days, in the three dimensional Not-AND (3D NAND) device fabrication, the number of silicon nitride/silicon oxide $\left(\mathrm{SiN}_{\mathrm{x}} / \mathrm{SiO}_{\mathrm{y}}\right)$ stack is increasing and the thickness of one $\mathrm{SiN}_{\mathrm{x}} / \mathrm{SiO}_{\mathrm{y}}$ layer is decreasing continuously for higher memory density in the vertical direction. Therefore, the etching of $\operatorname{SiN}_{x}$ layers uniformly and ultra-high selectively to $\mathrm{SiO}_{\mathrm{y}}$ layers in the $\mathrm{SiN}_{\mathrm{x}} / \mathrm{SiO}_{\mathrm{y}}$ stack is becoming more challenging process. Until now, the selective etching of $\mathrm{SiN}_{\mathrm{x}}$ in $\mathrm{SiN}_{\mathrm{x}} / \mathrm{SiO}_{\mathrm{y}}$ stacks is achieved by wet etching using a hot phosphoric acid $\left(\mathrm{H}_{3} \mathrm{PO}_{4}\right)$ [3-6]. In case of the wet etching, however, the penetration of an etch solution into holes is getting more challenging as the thickness of the $\mathrm{SiN}_{\mathrm{x}} / \mathrm{SiO}_{\mathrm{y}}$ layer is decreased and the remaining $\mathrm{SiO}_{y}$ layers can be collapsed due to the surface tension. Moreover, several additives for increasing the etch selectivity of $\mathrm{SiN}_{\mathrm{x}} / \mathrm{SiO}_{\mathrm{y}}$ are found to cause oxide regrowth problems after etching unless its process condition is not carefully controlled[6]. To solve these problems, a dry process for isotropic and selective etching of $\mathrm{SiN}_{\mathrm{x}}$ needs to be developed as an alternative technology for 3D NAND device fabrication.

Various studies have been reported for selective etching of $\mathrm{SiN}_{\mathrm{x}}$ over $\mathrm{SiO}_{\mathrm{y}}$ using dry etch processes. For example, an ultra-high selective etching of $\mathrm{SiN}_{\mathrm{x}}$ over $\mathrm{SiO}_{\mathrm{y}}$ was reported using $\mathrm{CF}_{4}$-based $\left(\mathrm{CF}_{4} / \mathrm{O}_{2} / \mathrm{N}_{2}\right.$, $\mathrm{CF}_{4} / \mathrm{CH}_{4} / \mathrm{Ar}$ ) gases with a microwave chemical downstream etcher and an inductively coupled plasma (ICP) etcher[7-9]. In addition, $\mathrm{NF}_{3}$-based $\left(\mathrm{NF}_{3} / \mathrm{O}_{2} / \mathrm{NH}_{3}, \mathrm{NF}_{3} / \mathrm{O}_{2} / \mathrm{N}_{2}\right)$ gases was used to ultra-high selective 
etching of silicon nitride over silicon oxide with downstream etchers based on inductively coupled plasma (ICP) or capacitively coupled plasma (CCP)[9-13]. However, the use of carbon-containing etch gases without adequate additive gases may result in a carbon-contamination or deposition of $\mathrm{CH}_{\mathrm{x}}$ polymer on the surface of silicon nitride. Also, due to the high global warming potentials (GWPs) of $\mathrm{CF}_{4^{-}}$and $\mathrm{NF}_{3^{-}}$ based etch gases [GWP values; $\left.\mathrm{CF}_{4}(7,390), \mathrm{NF}_{3}(17,200)\right]$, alternative etch gases need to be studied for environmental aspects in the near future[14].

$\mathrm{ClF}_{3}$ with the GWP of $\sim 0$ have been used primarily as an in-situ cleaning gas for chemical vapor deposition (CVD) chambers in replacement of perfluorocarbon compounds (PFC), which have high GWP values or as an etch gas for silicon etching by heating, neutral cluster beam etching, reactive ion beam etching, etc. [15-19]. In this study, $\mathrm{ClF}_{3}$ remote plasma was applied for a fast and ultra-high selective etching of silicon nitride $\left(\mathrm{SiN}_{\mathrm{x}}\right)$ over silicon oxide $\left(\mathrm{SiO}_{y}\right)$. The etching of $\mathrm{SiN}_{\mathrm{x}}$ using $\mathrm{ClF}_{3}$ showed high etch rate over $800 \AA /$ min and the etch selectivity of $\mathrm{SiN}_{\mathrm{x}}$ over $\mathrm{SiO}_{\mathrm{y}}$ of $\sim 130$. The etch selectivity of $\operatorname{SiN}_{\mathrm{x}}$ was further increased with $\mathrm{H}_{2}$ addition in the $\mathrm{ClF}_{3}$ plasma. The effect of $\mathrm{Cl}, \mathrm{F}$, and $\mathrm{H}$ radicals on the selective etching of $\mathrm{SiN}_{\mathrm{x}}$ was investigated using plasma and surface analysis tools, and its etch mechanism was suggested.

\section{Experimental Section}

\subsection{Etching of silicon nitride.}

Figure 1 is a schematic drawing of a remote type inductively coupled plasma (ICP) etching system used in this study. $13.56 \mathrm{MHz}$ RF power was applied to the planar type ICP coil at upper side of a chamber. For the isotropic etching of $\mathrm{SiN}_{\mathrm{x}}$, double grids with multiple holes with $1.5 \mathrm{~mm}$ radius were arranged at the center of ICP reactor to prevent an ion bombardment effect and deliver radicals on the substrate. The substrate temperature was adjusted from 25 to $500^{\circ} \mathrm{C}$ by a silicon carbide (SiC) heater connected to an external power supply. The chlorine trifluoride $\left(\mathrm{ClF}_{3}, 200 \mathrm{sccm}\right)$ and Argon ( $\left.\mathrm{Ar}, 200 \mathrm{sccm}\right)$ were flown through a circular shape gas distributor to the process chamber and the operating pressure was maintained at 200 mTorr.

\subsection{Sample preparation.}

Blank $1.5 \mu \mathrm{m}$ thick $\mathrm{SiN}_{\mathrm{x}}$ thin films and blank $300 \mathrm{~nm}$ thick $\mathrm{SiO}_{\mathrm{y}}$ thin films, and multilayer stacks composed of repeating $\mathrm{SiO}_{\mathrm{y}}(270 \AA)$ and $\mathrm{SiN}_{\mathrm{x}}(270 \AA)$ thin films deposited by a plasma enhanced chemical vapor deposition (PECVD) process (supplied by WONIK IPS Inc.) were used in this experiment.

\subsection{Characterization.}

The etch rate of $\mathrm{SiN}_{\mathrm{x}}$ and $\mathrm{SiO}_{\mathrm{y}}$ were measured by a step profilometer (Tencor, Alpha-step 500) and with Scanning Emission Microscopy (SEM, Hitachi S-4700) after patterning with photoresist (PR, AZ 5214E) as an etch mask. Also, the etch profiles of the multilayer thin films composed of $\mathrm{SiN}_{\mathrm{x}} / \mathrm{SiO}_{\mathrm{y}}$ stacks were 
observed by the SEM. The surface roughness of films after the etching was measured by atomic force microscope (AFM, XE-100, Park System) with a non-contact measurement mode. The characteristics of $\mathrm{ClF}_{3} / \mathrm{H}_{2}$ plasma were analyzed with Optical Emission Spectrometry (OES, Avaspec-3648). Byproduct gases during etching process were monitored with Fourier-Transform Infrared Spectroscopy (FT-IR, MIDAC 12000). The binding state and atomic composition of $\mathrm{SiN}_{x}$ and $\mathrm{SiO}_{y}$ (thin films of initial thickness of 5000, $3000 \AA$, respectively) before and after the etching were analyzed by X-ray Photoelectron Spectroscopy (XPS, MXP10, ThermoFisher Scientific) with a monochromated Al Ka source $(1,486.6 \mathrm{eV})$ with spot size of $400 \mu \mathrm{m}$. The expected energy resolution of XPS is below $0.5 \mathrm{eV} \mathrm{FWHM.} \mathrm{The} \mathrm{Avantage}$ 5.0 software was used for curve fittings and the areas of each peak were calculated with shirley background. The incident angle of X-ray to the sample was $50^{\circ}$ and a hemispherical sector energy analyzer was positioned perpendicular to the sample stage.

\section{Results And Discussion}

Figure 2 shows etch characteristics of $\mathrm{SiN}_{x}$ and $\mathrm{SiO}_{y}$ with $\mathrm{ClF}_{3}$ gas only and $\mathrm{ClF}_{3}$ remote plasmas. For $\mathrm{ClF}_{3}$ remote plasmas, $200 \mathrm{sccm}$ of $\mathrm{Ar}$ was added to $200 \mathrm{sccm}$ of $\mathrm{ClF}_{3}$ for the plasma stability. As shown in figure 2a), the etch rates of $\mathrm{SiN}_{x}$ and $\mathrm{SiO}_{y}$ were increased gradually with increasing if power due to the enhanced dissociation of $\mathrm{ClF}_{3}$ reaching the maximum etch rates of $\mathrm{SiN}_{\mathrm{x}}$ and $\mathrm{SiO}_{\mathrm{y}}$ at $\sim 900$ and $~ 8.1$ $\AA /$ min, respectively. Note that, the etch selectivity of $\mathrm{SiN}_{\mathrm{x}}$ over $\mathrm{SiO}_{\mathrm{y}}$ didn't vary significantly $(\sim 120)$ over rf powers of $100 \sim 400 \mathrm{~W}$. In fact, as shown in figure 2 (b), the $\mathrm{SiN}_{\mathrm{x}}$ and $\mathrm{SiO}_{\mathrm{y}}$ could be also etched just by flowing $\mathrm{ClF}_{3}$ gas only without dissociating $\mathrm{ClF}_{3}$ by rf plasmas and the increase of substrate temperature increased the etch rates. However, the overall $\mathrm{SiN}_{\mathrm{x}}$ etch rates by $\mathrm{ClF}_{3}$ gas flow only were much lower compared to etching with $\mathrm{ClF}_{3}$ remote plasmas, and which demonstrates that $\mathrm{ClF}_{3}$ remote plasma etching is much more effective method for $\mathrm{SiN}_{\mathrm{x}}$ etching compared with that by thermal etching without plasma. Meanwhile, even though etch rates of both materials were increased with increasing the substrate temperature, the etch selectivity of $\mathrm{SiN}_{\mathrm{x}}$ over $\mathrm{SiO}_{\mathrm{y}}$ was decreased. Therefore, as shown in figure 2c), when the etch rates of $\mathrm{SiN}_{x}$ and $\mathrm{SiO}_{y}$ were measured as a function of if power at the substrate temperature of $100{ }^{\circ} \mathrm{C}$, the similar trend was observed as those in figure $2 \mathrm{a}$ ) while showing higher the $\mathrm{SiN}_{\mathrm{x}}$ etch rates (above $2000 \AA / \mathrm{min}$ at $400 \mathrm{~W}$ of rf power) and lower etch selectivities ( 60 at $400 \mathrm{~W}$ of rf power). Also, as shown in figure $2 \mathrm{~d}$ ), the further increase of substrate temperature to $\sim 500{ }^{\circ} \mathrm{C}$ at a fixed if power of $300 \mathrm{~W}$ showed the further decreases of etch selectivity below 40 while showing increased $\operatorname{SiN}_{x}$ etch rates over $6000 \AA /$ min. Figure 3a) shows the selected etch rates of $\mathrm{SiN}_{\mathrm{x}}$ and $\mathrm{SiO}_{\mathrm{y}}$ for chemical etching with $\mathrm{ClF}_{3}$ gas only at $100{ }^{\circ} \mathrm{C}, \mathrm{ClF}_{3}$ remote plasma etching (300 W) at $\mathrm{RT}$, and $\mathrm{ClF}_{3}$ remote plasma etching at $100{ }^{\circ} \mathrm{C}$ in figure 2 to illustrate the effect of plasma more clearly. As shown in figure 3a), for the chemical etching of $\mathrm{SiN}_{\mathrm{x}}$ with $\mathrm{ClF}_{3}$, it clearly showed that the addition of remote plasma to thermal etching significantly increased the etch rate of $\mathrm{SiN}_{x}$ without decreasing the etch selectivity over $\mathrm{SiO}_{\mathrm{y}}$ significantly due to the more reaction species on the surface by reactive radicals generated by the remote plasma. In addition to the role of the remote plasma, the role of process temperature on the etching of 
$\mathrm{SiN}_{\mathrm{x}}$ and $\mathrm{SiO}_{\mathrm{y}}$ can be understood by plotting the etch rates of $\mathrm{SiN}_{\mathrm{x}}$ and $\mathrm{SiO}_{\mathrm{y}}$ logarithmically as a function of inverse temperature $(1 / \mathrm{T})$ for $\mathrm{ClF}_{3}$ remote plasma etching as shown in figure $\left.3 \mathrm{~b}\right)$. For the chemically activated etching, the etch rates can be described as a following Arrhenius equation.

$$
\ln k=-\frac{E_{a}}{R}\left(\frac{1}{T_{2}}-\frac{1}{T_{1}}\right)
$$

where $k$ is a rate constant, $R$ is the gas constant $\left(8.31 \mathrm{~J} \mathrm{~K}^{-1} \mathrm{~mol}^{-1}\right)$, and $E_{a}$ is the activation energy. The calculated activation energies $\left(E_{a}\right)$ of $\operatorname{SiN}_{x}$ and $\mathrm{SiO}_{\mathrm{y}}$ were $3.09 \times 10^{-20}$ and $5.08 \times 10^{-20} \mathrm{~J} / \mathrm{mole}$, respectively. The higher activation energy of $\mathrm{SiO}_{y}$ means that the etch rate of $\mathrm{SiO}_{y}$ rises faster than that of $\mathrm{SiN}_{\mathrm{x}}$ with the increase of temperature, and which leads to the decreases in etch selectivity of $\mathrm{SiN}_{\mathrm{x}}$ over $\mathrm{SiO}_{y}$ even though the etch rates of both materials are increased exponentially with increasing substrate temperature. When the RMS surface roughness values of $\mathrm{SiN}_{\mathrm{x}}$ and $\mathrm{SiO}_{\mathrm{y}}$ were measured before and after the etching of $\sim 400 \mathrm{~nm}$ and $\sim 20 \mathrm{~nm}$, respectively, with the etch methods in figure 3a), no significant differences in RMS surface roughness among the etch methods could be observed for both $\mathrm{SiN}_{\mathrm{x}}$ and $\mathrm{SiO}_{\mathrm{y}}$ (shown in figure $\mathrm{S} 1$, supplementary information).

To improve the etch selectivity of $\mathrm{SiN}_{\mathrm{x}}$ over $\mathrm{SiO}_{\mathrm{y}}, \mathrm{H}_{2}$ was added to $\mathrm{ClF}_{3}$ in addition to $\mathrm{Ar}$ ( $\mathrm{Ar}$ was also added to $\mathrm{ClF}_{3} / \mathrm{H}_{2}$ for plasma stability) and, the effect of $\mathrm{H}_{2}$ addition to $\mathrm{ClF}_{3}$ on the etch characteristics of $\mathrm{SiN}_{\mathrm{x}}$ and $\mathrm{SiO}_{\mathrm{y}}$ was investigated as a function of $\mathrm{H}_{2}$ percentage in $\mathrm{ClF}_{3} / \mathrm{H}_{2}\left(\mathrm{ClF}_{3} / \mathrm{H}_{2} / \mathrm{Ar}\right.$ plasma) and the results are shown in figure $4 a$ ). To increase the $\mathrm{H}_{2}$ percentage in $\mathrm{ClF}_{3} / \mathrm{H}_{2}, \mathrm{H}_{2}$ flow rate was increased while keeping the substrate temperature at $25^{\circ} \mathrm{C}$, operating pressure at $200 \mathrm{mTorr}$, the $\mathrm{ClF}_{3}$ flow rate at $200 \mathrm{sccm}$, Ar flow rate at $200 \mathrm{sccm}$, and the rf power at $300 \mathrm{~W}$. As shown in figure 4a), the etch rates of both $\mathrm{SiN}_{\mathrm{x}}$ and $\mathrm{SiO}_{\mathrm{y}}$ were decreased with the increase of $\mathrm{H}_{2}$ percentage, however, the etch selectivity of $\mathrm{SiN}_{x}$ over $\mathrm{SiO}_{y}$ was increased with the increase of $\mathrm{H}_{2}$ percentage in $\mathrm{ClF}_{3} / \mathrm{H}_{2}$. To study the mechanism on the etching of $\mathrm{SiN}_{x}$ and the etch selectivity over $\mathrm{SiO}_{y}$, the dissociated species in the plasmas and the byproducts at the pumping site were observed using OES and FTIR, respectively. Figure 4b) and c) shows optical emission spectra and the relative emission peak intensities of $\mathrm{Cl}, \mathrm{F}$, and $\mathrm{H}$ normalized by the intensity of $\mathrm{Ar}$ as a function of $\mathrm{H}_{2}$ percentage in $\mathrm{ClF}_{3} / \mathrm{H}_{2}$, respectively. In figure $4 b$ ), the optical emission peak intensities related to $\mathrm{Cl}, \mathrm{H}, \mathrm{F}$, and $\mathrm{Ar}$ could be measured at 280,656, 704, and $750 \mathrm{~nm}$, respectively. In figure $4 \mathrm{C}$ ), the optical emission intensities of $\mathrm{Cl}, \mathrm{F}$, and $\mathrm{H}$ were normalized by the optical emission intensity of $\operatorname{Ar}(750 \mathrm{~nm})$ to minimize the effect of electron density on the estimation of radical density from the emission intensity. As shown in figure 4c), the increase of $\mathrm{H}_{2}$ percentage did not change the intensity of $\mathrm{Cl}$, however, it decreased $\mathrm{F}$ intensity while increasing $\mathrm{H}$ intensity. Figure $4 \mathrm{~d}$ ) shows the FTIR data of the byproduct gases such as $\mathrm{SiF}_{4}$ and $\mathrm{HF}$ measured at the pumping site for different $\mathrm{H}_{2}$ percentage in $\mathrm{ClF}_{3} / \mathrm{H}_{2}$. As the flow rate of $\mathrm{H}_{2}$ is increased, the concentration of $\mathrm{SiF}_{4}$ was decreased while increasing $\mathrm{HF}$ concentration due to the reaction of hydrogen $(\mathrm{H})$ with fluorine $(\mathrm{F})$ radical in the plasma. 
Therefore, from the figure (b), c), and d), it is found that the decrease of etch rates of both $\mathrm{SiN}_{\mathrm{x}}$ and $\mathrm{SiO}_{\mathrm{y}}$ are related to the scavenging $\mathrm{F}$ radicals in the plasma by the formation of $\mathrm{HF}[19]$, which has negligible effects on the etching of $\mathrm{SiN}_{\mathrm{x}}$ unlike its aqueous (ionic) state[20, 21], in the plasma with increasing $\mathrm{H}_{2}$ percentage.

The Si binding states and compositions of the surfaces of $\mathrm{SiN}_{\mathrm{x}}$ and $\mathrm{SiO}_{\mathrm{y}}$ during the $\mathrm{ClF}_{3} / \mathrm{H}_{2}$ plasma etching were analyzed using X-ray Photoelectron Spectroscopy (XPS) and the results are shown in figure 5a-c) and d-f) for $\mathrm{SiN}_{\mathrm{x}}$ and $\mathrm{SiO}_{\mathrm{y}}$, respectively, and also in Table 1. $\mathrm{SiN}_{\mathrm{x}}$ and $\mathrm{SiO}_{\mathrm{y}}$ were etched at the substrate temperature of $25{ }^{\circ} \mathrm{C}$, operating pressure at $200 \mathrm{mTorr}$, the $\mathrm{ClF}_{3} / \mathrm{H}_{2} / \mathrm{Ar}$ flow rates at $200 /(0$ and 40)/200 sccm, and the if power at $300 \mathrm{~W}$. After the etching with $\mathrm{ClF}_{3}$ plasma, significant Si-F bonding $(103.6 \mathrm{eV})$ was formed on the $\mathrm{SiN}_{\mathrm{x}}$ surface, presumably due to the bonding of Si with F (figure $5 \mathrm{~b}$ ). The Si-F bonding ratio decreases with addition of $\mathrm{H}_{2}(20 \%)$ because of the reduction of $\mathrm{F}$ in the plasma (figure $5 \mathrm{c}$ and Table 1). However, no chlorine or Si-Cl bonding $(\sim 103.3 \mathrm{eV})$ was observed on the surface of $\mathrm{SiN}_{\mathrm{x}}$ even though there were enough $\mathrm{Cl}$ radicals in the $\mathrm{ClF}_{3} / \mathrm{H}_{2}$ plasma as confirmed through OES data in figure 4c), presumably, due to the immediate reaction of $\mathrm{Si}-\mathrm{Cl}$ with $\mathrm{F}$ radicals. Meanwhile, as shown in figure $5 \mathrm{e}$, $\mathrm{f}$ ), there was no significant change in $\mathrm{F}$ concentration on the $\mathrm{SiO}_{\mathrm{y}}$ surface during etching with $\mathrm{ClF}_{3}$ and $\mathrm{ClF}_{3} / \mathrm{H}_{2}$ plasma. Also, no noticeable Si-F bonding formation on the $\mathrm{SiO}_{\mathrm{y}}$ surface during the etching with $\mathrm{ClF}_{3}$ and $\mathrm{ClF}_{3} / \mathrm{H}_{2}$ plasma was observed from the deconvolution of Si narrow scan data (Si $2 p$ ) indicating that most of $\mathrm{F}$ is adsorbed on the $\mathrm{SiO}_{\mathrm{y}}$ surface after the etching. Furthermore, the amount of $\mathrm{F}$ on the $\mathrm{SiO}_{\mathrm{y}}$ surface is much lower than that of $\mathrm{SiN}_{\mathrm{x}}$ because $\mathrm{Si}-\mathrm{O}$ bonding is less reactive with $\mathrm{F}$ radical compared with $\mathrm{SiN}_{\mathrm{x}}$. The parameters used for curve fitting of $\mathrm{SiN}_{\mathrm{x}}$ is described in Table 1 and the normalized chisquare value for curve fitting was below 0.01 . The compositional information of each element can be found in Table S1, supplementary information.

\section{Table 1}

Parameters related with the curve fitting of silicon nitride $\left(\mathrm{SiN}_{\mathrm{x}}\right)$ thin films after exposure to the $\mathrm{ClF}_{3}$ only and $\mathrm{ClF}_{3} \& \mathrm{H}_{2}(20 \%)$ plasma

\begin{tabular}{|c|c|c|c|c|c|}
\hline Sample & Binding state & B.E. (eV) & FWHM (eV) & $\%$ Area & Gaussian \% \\
\hline \multirow[t]{3}{*}{$\mathrm{SiN}_{\mathrm{x}}\left(\mathrm{ClF}_{3}\right.$ only $)$} & Si $2 p$ & 99.7 & 1.3 & 1.6 & 88.8 \\
\hline & Si-N & 101.7 & 1.7 & 84.5 & 87.5 \\
\hline & Si-F & 103.6 & $1.55( \pm 0.05)$ & 13.9 & 85.7 \\
\hline \multirow{3}{*}{$\begin{array}{l}\text { SiNx } \\
\text { [CIF3 \& H2 (20\%)] }\end{array}$} & Si $2 p$ & 99.7 & 1.3 & 1.6 & 88.8 \\
\hline & Si-N & 101.7 & 1.7 & 88 & 87.5 \\
\hline & $\mathrm{Si}-\mathrm{F}$ & 103.6 & $1.55( \pm 0.05)$ & 10.4 & 85.7 \\
\hline
\end{tabular}


The etching of $\mathrm{SiN}_{\mathrm{x}}$ and $\mathrm{SiO}_{\mathrm{y}}$ can be explained through the bonding energies of silicon (Si) compounds. Figure 6 shows the etch mechanism of $\mathrm{SiN}_{\mathrm{x}}$ and $\mathrm{SiO}_{\mathrm{y}}$ under $\mathrm{Cl}, \mathrm{F}$ radicals. As the bonding energy of $\mathrm{Si}-\mathrm{F}$ $(565 \mathrm{KJ} / \mathrm{mol})$ is higher than those of Si-N $(355 \mathrm{KJ} / \mathrm{mol})$ and Si-O $(452 \mathrm{KJ} / \mathrm{mol})$ [22], the $\mathrm{SiN}_{\mathrm{x}}$ and $\mathrm{SiO}_{\mathrm{y}}$ can be etched spontaneously under sufficient $\mathrm{F}$ radicals in the plasma although the etching is much active for $\mathrm{SiN}_{\mathrm{x}}$ than $\mathrm{SiO}_{\mathrm{y}}$. However, the bonding energy of $\mathrm{Si}-\mathrm{Cl}(381 \mathrm{KJ} / \mathrm{mol})$ is slightly higher than that of Si-N but lower than that of $\mathrm{Si}-\mathrm{O}$, and which means the $\mathrm{Cl}$ radical can react only with $\mathrm{SiN}_{\mathrm{x}}$ and forms $\mathrm{Si}-\mathrm{Cl}$ bonding. Once the Si-N changes to $\mathrm{Si}-\mathrm{Cl}, \mathrm{Si}-\mathrm{Cl}$ can be more easily converted to Si-F by F radicals in the plasma (due to the quick conversion of $\mathrm{Si}-\mathrm{Cl}$ to $\mathrm{Si}-\mathrm{F}$ as shown in figure 5 , no chlorine could be observed on the surfaces of $\mathrm{SiN}_{\mathrm{x}}$ and $\mathrm{SiO}_{\mathrm{y}}$ during the etching with $\mathrm{ClF}_{3} / \mathrm{H}_{2}$ ), then $\mathrm{Si}-\mathrm{F}$ on $\mathrm{SiN}_{\mathrm{x}}$ is removed as a volatile $\mathrm{SiF}_{4}$ compound. Meanwhile, the addition of $\mathrm{H}_{2}$ in the $\mathrm{ClF}_{3}$ plasma reduces the density of $\mathrm{F}$ radicals by forming $\mathrm{HF}$ in the plasma causing the decreases of Si-F formation on the surfaces of $\mathrm{SiN}_{\mathrm{x}}$ and $\mathrm{SiO}_{\mathrm{y}}$, and which results in the decrease of etch rates of $\mathrm{SiN}_{\mathrm{x}}$ and $\mathrm{SiO}_{y}$. However, because the concentration of chlorine in the plasma is not significantly affected by the addition of $\mathrm{H}_{2}$ as confirmed through OES data in figure 4c), the etching of $\mathrm{SiN}_{\mathrm{x}}$ is decreased more slowly compared to that of $\mathrm{SiO}_{\mathrm{y}}$ with increasing $\mathrm{H}_{2}$ percentage through the conversion of $\mathrm{Si}-\mathrm{Cl}$ on the surface of $\mathrm{SiN}_{\mathrm{x}}$ to $\mathrm{Si}-\mathrm{F}$, and which appears to increases the etch selectivity of $\mathrm{SiN}_{\mathrm{x}}$ over $\mathrm{SiO}_{\mathrm{y}}$.

Using the etch conditions of $\mathrm{ClF}_{3}$ and $\mathrm{ClF}_{3} / \mathrm{H}_{2}(20 \%)$, stacked layers of $\mathrm{SiN}_{\mathrm{x}} / \mathrm{SiO}_{\mathrm{y}}$ were etched and the results are shown in figure 7. Figure 7a) is the reference stack of $\mathrm{SiN}_{\mathrm{x}} / \mathrm{SiO}_{\mathrm{y}}$ before the etching. Figure $7 \mathrm{~b}$ ) and c) are the stacked layer of $\mathrm{SiN}_{\mathrm{x}} / \mathrm{SiO}_{\mathrm{y}}$ after the etching using $\mathrm{ClF}_{3}$ and $\mathrm{ClF}_{3} / \mathrm{H}_{2}(20 \%)$ plasmas for 5 min and 10 min, respectively. As shown in figure 7b) and c), highly selective etching of $\mathrm{SiN}_{\mathrm{x}}$ over $\mathrm{SiO}_{\mathrm{y}}$ could be observed for both $\mathrm{ClF}_{3}$ and $\mathrm{ClF}_{3} / \mathrm{H}_{2}(20 \%)$ by showing no noticeable differences in $\mathrm{SiO}_{y}$ thickness along the etch depth. Therefore, it appears that the etch selectivity for the real $\mathrm{SiN}_{\mathrm{x}} / \mathrm{SiO}_{\mathrm{y}}$ could be higher than that measured with blank wafers. The etch depth with increasing the etch time was also measured and the results are shown in d) for both $\mathrm{ClF}_{3}$ and $\mathrm{ClF}_{3} / \mathrm{H}_{2}(20 \%)$. The etch depth with etch time was linear for both conditions, therefore, no aspect ratio dependent etching was observed. (The process time-dependent etch profiles of $\mathrm{SiN}_{\mathrm{x}} / \mathrm{SiO}_{\mathrm{y}}$ stacks are shown in figure $\mathrm{S} 2$ and $\mathrm{S} 3$, supplementary information).

\section{Conclusion}

The isotropic and selective etching of $\mathrm{SiN}_{\mathrm{x}}$ over $\mathrm{SiO}_{\mathrm{y}}$ was studied using $\mathrm{ClF}_{3} / \mathrm{H}_{2}$ remote plasma with an ICP source. The $\mathrm{SiN}_{\mathrm{x}}$ etching using plasma assisted thermal processes showed the highest etch rate as well as the smoothest surface morphology compared with that etched only with thermal etching or plasma etching. During the plasma etching, the etch rate of $\mathrm{SiN}_{\mathrm{x}}$ was increased with increasing process temperature but the selectivity over $\mathrm{SiO}_{y}$ was found to be decreased due to the higher activation energy of $\mathrm{SiO}_{y}$ compared with that of $\mathrm{SiN}_{x}$ with $\mathrm{ClF}_{3}$ plasma. The addition of $\mathrm{H}_{2}(20 \%)$ to the $\mathrm{ClF}_{3}$ plasma improved the etch selectivity of $\mathrm{SiN}_{\mathrm{x}}$ over $\mathrm{SiO}_{y}$ from 130 to 200 even though the etch rate of $\mathrm{SiN}_{\mathrm{x}}$ was decreased 
from $\sim 830$ to $\sim 230 \AA$ /min. We believe the fast and ultra-high selective $\operatorname{SiN}_{\mathrm{x}}$ etching technology can be applied not only to next generation 3D NAND process but also to various semiconductor processes where precise etching of $\mathrm{SiN}_{\mathrm{x}}$ is required.

\section{Declarations}

\section{Acknowledgments}

This research was supported by the MOTIE [Ministry of Trade, Industry \& Energy (20003665)] and KSRC (Korea Semiconductor Research Consortium) support program for the development of the future semiconductor device. This research was also supported by Samsung Electronics Co., Ltd. (IO20121108086-01). The authors would like to thank to Wonik IPS for the supply of $\mathrm{SiN}_{\mathrm{x}} / \mathrm{SiO}_{\mathrm{y}}$ stack wafer and to Wonik Materials for the supply of $\mathrm{ClF}_{3}$ gas.

\section{Conflicts of interest}

There are no conflicts to declare.

\section{References}

1. M. M. Mirza, H. Zhou, P. Velha, X. Li, K. E. Docherty, A. Samarelli, D. J. Paul, J. Vac. Sci. Technol. B, 2012, 30, 06FF02. (2012).

2. D. Seo, J. S. Bae, E. Oh, S. Kim, S. Lim, Microelectron. Eng., 2014, 118, 66-71.

3. D. Bassett, W. Printz, T. Furukawa, ECS Trans., 2015, 69, 159.

4. Y. H. C. Chien, C. C. Hu, C. M. Yang, J. Electrochem. Soc., 2018, 165, H3187.

5. T. Kim, C. Son, T. Park, S. Lim, Microelectron. Eng., 2020, 221, 111191.

6. M. Bouchilaoun, A. Soltani, A. Chakroun, A. Jaouad, M. Darnon, F. Boone, H. Maher, physica status solidi (A), 2018. 215, 1700658.

7. L. Chen, L. Xu, D. Li, B. Lin, Microelectron. Eng., 2009, 86, 2354-2357.

8. S. Lee, J. Oh, K. Lee, H. Sohn, J. Vac. Sci. Technol. B, 2010, 28, 131-137.

9. B. E. E. Kastenmeier, P. J. Matsuo, G. S. Oehrlein, J. Vac. Sci. Technol. A, 1999, 17, 3179-3184.

10. H. Ogawa, T. Arai, M. Yanagisawa, T. Ichiki, Y. Horiike, Jpn. J. Appl. Phys., 2002, 41, 5349.

11. V. Volynets, Y. Barsukov, G. Kim, J. E. Jung, S. K. Nam, K. Han, S. Huang, M. J. Kushner, J. Vac. Sci. Technol. A, 2020, 38, 023007.

12. J. E. Jung, Y. Barsukov, V. Volynets, G. Kim, S. K. Nam, K. Han, S. Huang, M. J. Kushner, J. Vac. Sci. Technol. A, 2020, 38, 023008.

13. B. E. E. Kastenmeier, P. J. Matsuo, G. S. Oehrlein, J. G. Langan, J. Vac. Sci. Technol. A, 1998, 16, 2047-2056. 
14. R. Raju, D. Kudo, Y. Kubo, T. Inaba, H. Shindo, Jpn. J. Appl. Phys., 2003, 42, 280.

15. I. Mouri, S. Hayakawa, J. Agric. Meteorol., 1997, 52, 849-852.

16. D. L. Flamm, Pure Appl. Chem., 1990, 62, 1709-1720.

17. T. Seki, H. Yamamoto, T. Kozawa, T. Shojo, K. Koike, T. Aoki, J. Matsuo, Jpn. J. Appl. Phys., 2017, 56, $06 \mathrm{HB} 02$.

18. H. Yamamoto, T. Seki, J. Matsuo, K. Koike, T. Kozawa, Microelectron. Eng., 2015, 141, 145-149.

19. J. H. Kim, H. J. Lee, J. H. Joo, K. W. Whang, Appl. Sci. Converg. Technol., 1996, 5, 169-174.

20. D. Nakayama, A. Wada, T. Kubota, R. Bruce, R. M. Martin, M. Haass, N. Fuller, S. Samukawa, J. Phys. D., 2013, 46, 205203.

21. D. M. Knotter, T. D. Denteneer, J. Electrochem. Soc., 2001, 148, F43.

22. F. Tian, A. V. Teplyakov, Langmuir, 2013, 29, 13-28.

\section{Figures}




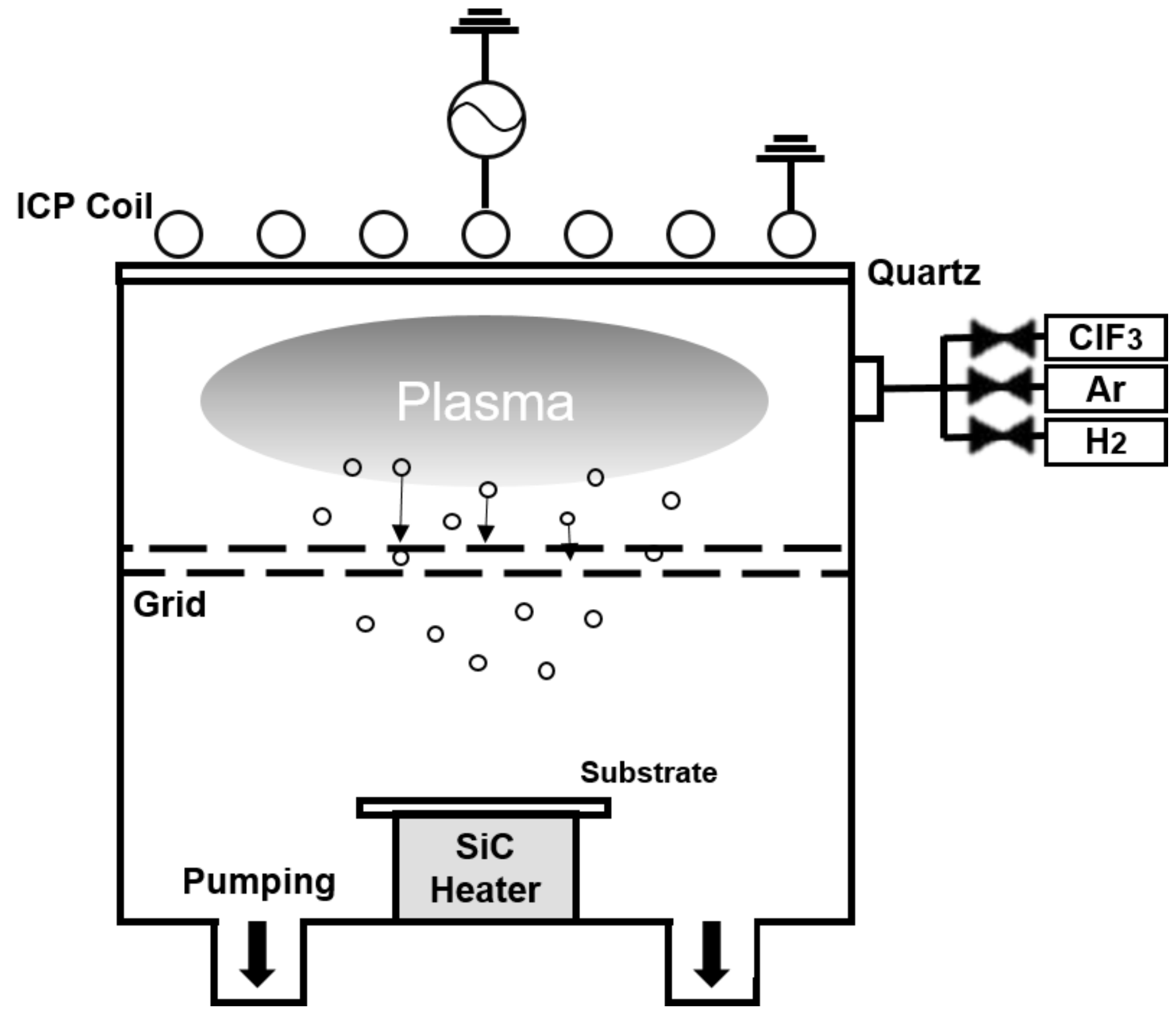

Figure 1

Schematic drawing of a remote-type inductively coupled plasma (ICP) etcher. At the center of the chamber, double grids having multiple holes are installed to prevent an ion bombardment and to deliver radicals only to the substrate. During the process, the substrate temperature was controlled (RT $\left.\sim 500{ }^{\circ} \mathrm{C}\right)$ by a silicon carbide ( $\mathrm{SiC})$ heater located below the substrate. 

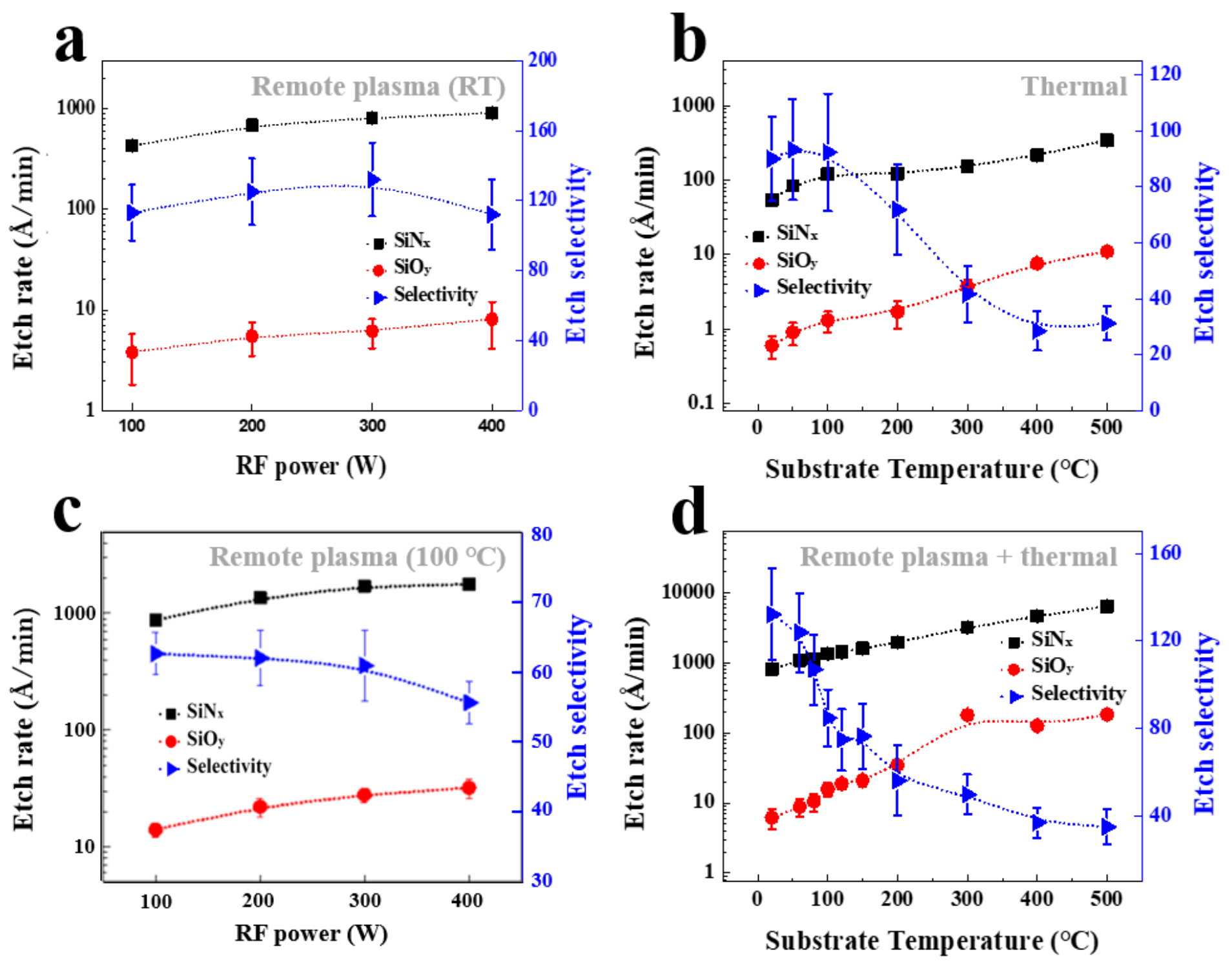

Figure 2

Etch characteristics of $\mathrm{SiN}_{\mathrm{x}}$ and $\mathrm{SiO}_{\mathrm{y}}$ a) as a function of if power for $\mathrm{ClF}_{3}$ remote plasma at $\mathrm{RT}, \mathrm{b}$ ) as a function of substrate temperature for chemical etching with $\mathrm{ClF}_{3}$ gas flow only, c) as a function of if power for $\mathrm{ClF}_{3}$ remote plasma at the substrate temperature of $100{ }^{\circ} \mathrm{C}$, and $\mathrm{d}$ ) as a function of substrate temperature for $\mathrm{ClF}_{3}$ remote plasma at $300 \mathrm{~W}$ of if power. $200 \mathrm{sccm} \mathrm{Ar}(200 \mathrm{sccm})$ was added to $\mathrm{ClF}_{3}$ for plasma stability. 

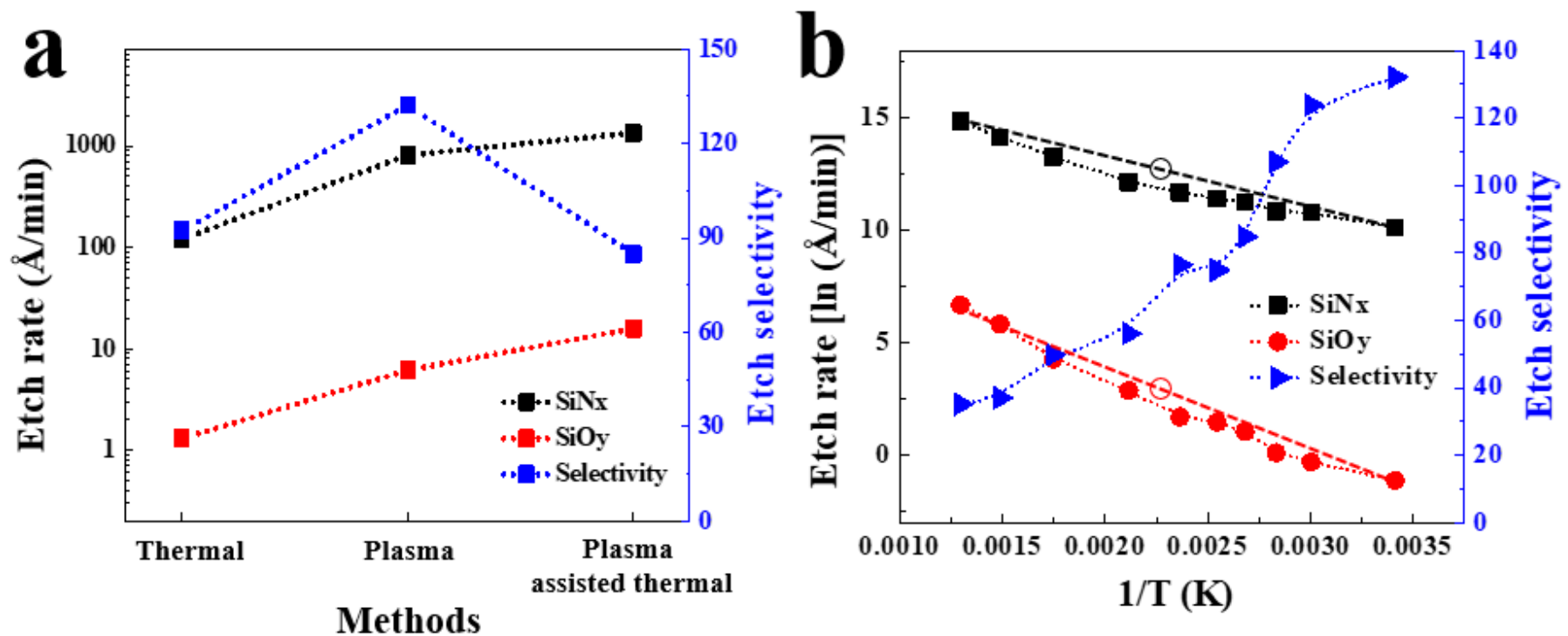

Figure 3

a) Selected etch rates of $\mathrm{SiN}_{x}$ and $\mathrm{SiO}_{y}$ for chemical etching with $\mathrm{ClF}_{3}$ gas only at $100{ }^{\circ} \mathrm{C}_{,} \mathrm{ClF}_{3}$ remote plasma etching ( $(300 \mathrm{~W})$ at $\mathrm{RT}$, and $\mathrm{ClF}_{3}$ remote plasma etching at $100{ }^{\circ} \mathrm{C}$ in figure 2 . b) logarithm etch rates versus $1 / \mathrm{T}$ for $\mathrm{ClF}_{3}$ remote plasma etching of $\mathrm{SiN}_{\mathrm{x}}$ and $\mathrm{SiO}_{\mathrm{y}}$ in figure 2 for the extraction of the activation energies. 


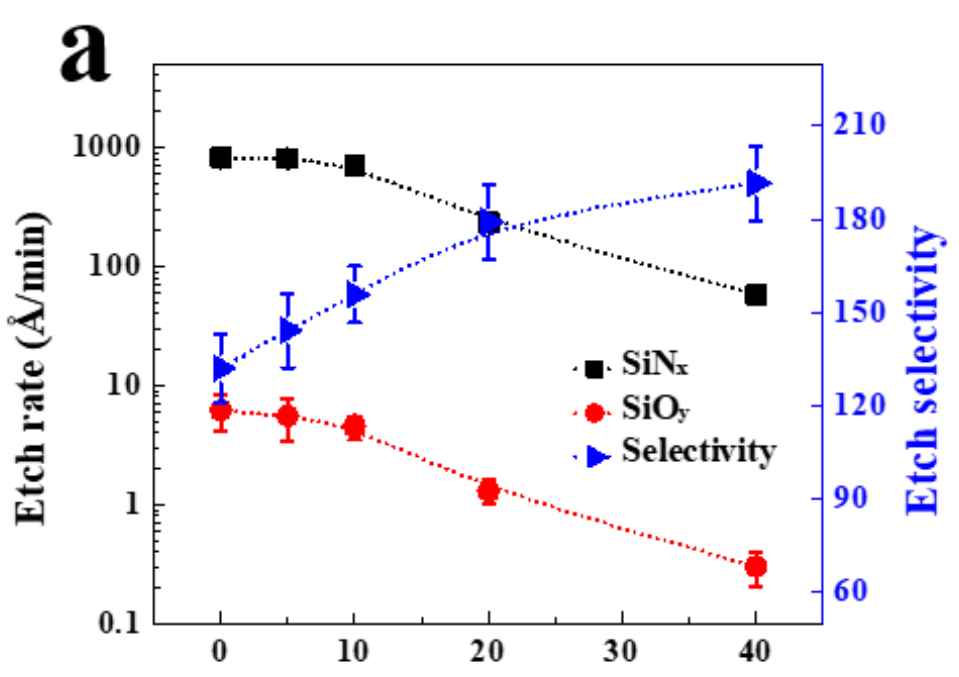

b

$\mathrm{H}_{2} \%$ in $\mathrm{ClF}_{3} / \mathrm{H}_{2}$

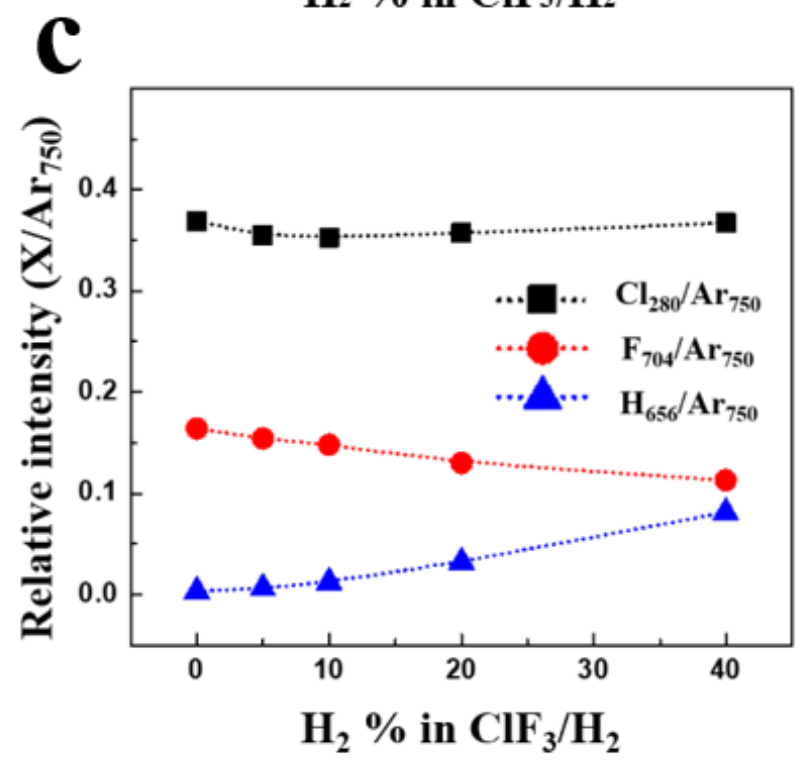

d

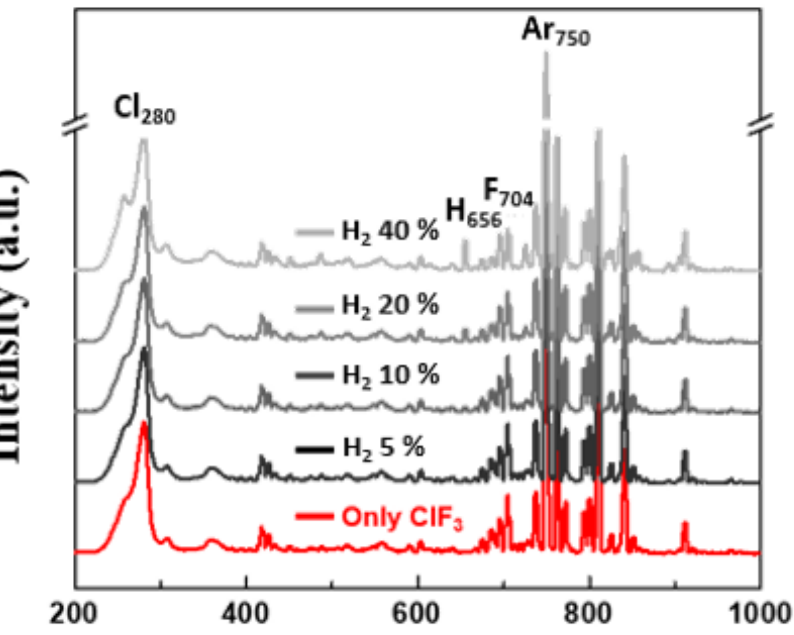

Wavelength (nm)

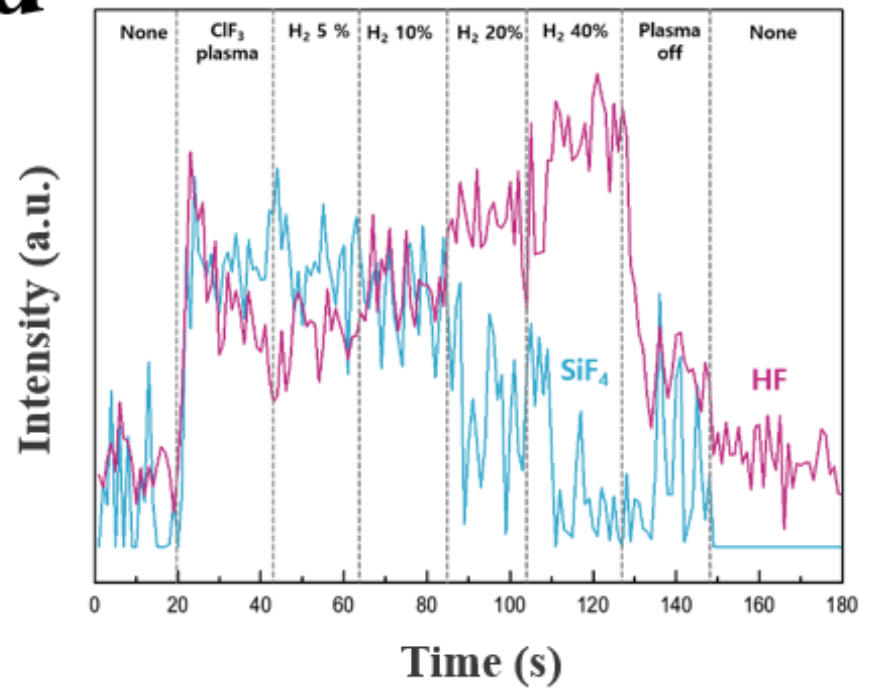

Figure 4

a) Etch characteristics of $\mathrm{SiN}_{\mathrm{x}}$ and $\mathrm{SiO}_{\mathrm{y}}$ with $\mathrm{ClF}_{3} / \mathrm{H}_{2}$ plasma as a function of $\mathrm{H}_{2}$ percentage in $\mathrm{ClF}_{3} / \mathrm{H}_{2}$.

b) $\mathrm{OES}$ data of $\mathrm{ClF}_{3} / \mathrm{H}_{2} /$ Ar plasma with different $\mathrm{H}_{2}$ percentage in $\mathrm{ClF}_{3} / \mathrm{H}_{2}$. c) optical emission intensities of $\mathrm{Cl}, \mathrm{F}$, and $\mathrm{H}$ normalized by the intensity of $\operatorname{Ar}(750 \mathrm{~nm})$ in b) plotted as a function of $\mathrm{H}_{2}$ percentage. d) FTIR data of $\mathrm{ClF}_{3} / \mathrm{H}_{2}$ plasma during $\mathrm{SiN}_{\mathrm{x}}$ etching. For $\mathrm{ClF}_{3} / \mathrm{H}_{2}$ remote plasmas, $200 \mathrm{sccm}$ of $\mathrm{Ar}$ was added for the plasma stability. 

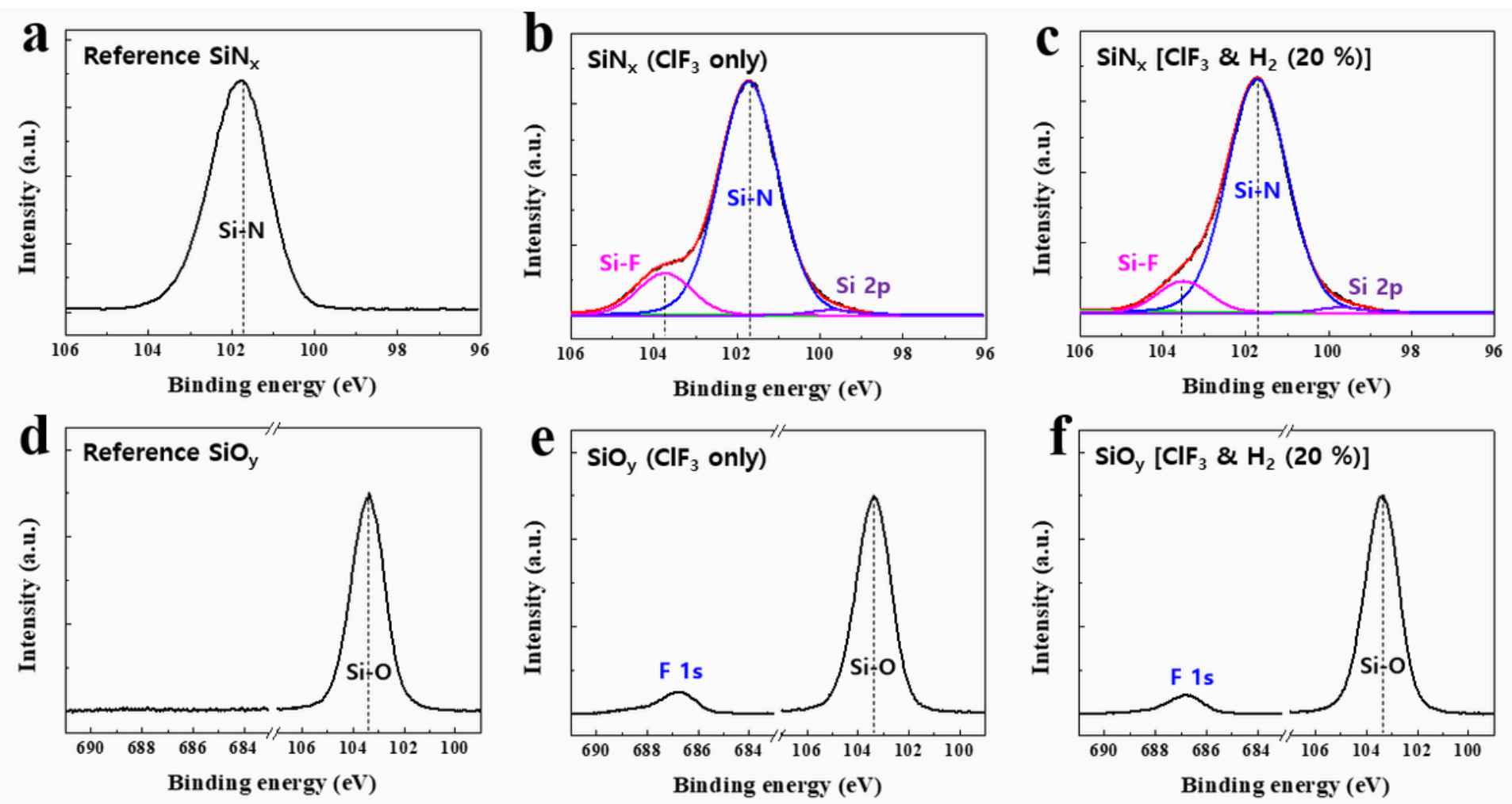

Figure 5

XPS narrow scan (Si 2p) data of $\mathrm{SiN}_{\mathrm{x}}(\mathrm{a}-\mathrm{c})$ and $\mathrm{SiO}_{\mathrm{y}}(\mathrm{d}-\mathrm{f})$ after etching with remote $\mathrm{ClF}_{3} / \mathrm{H}_{2}$ plasma. 

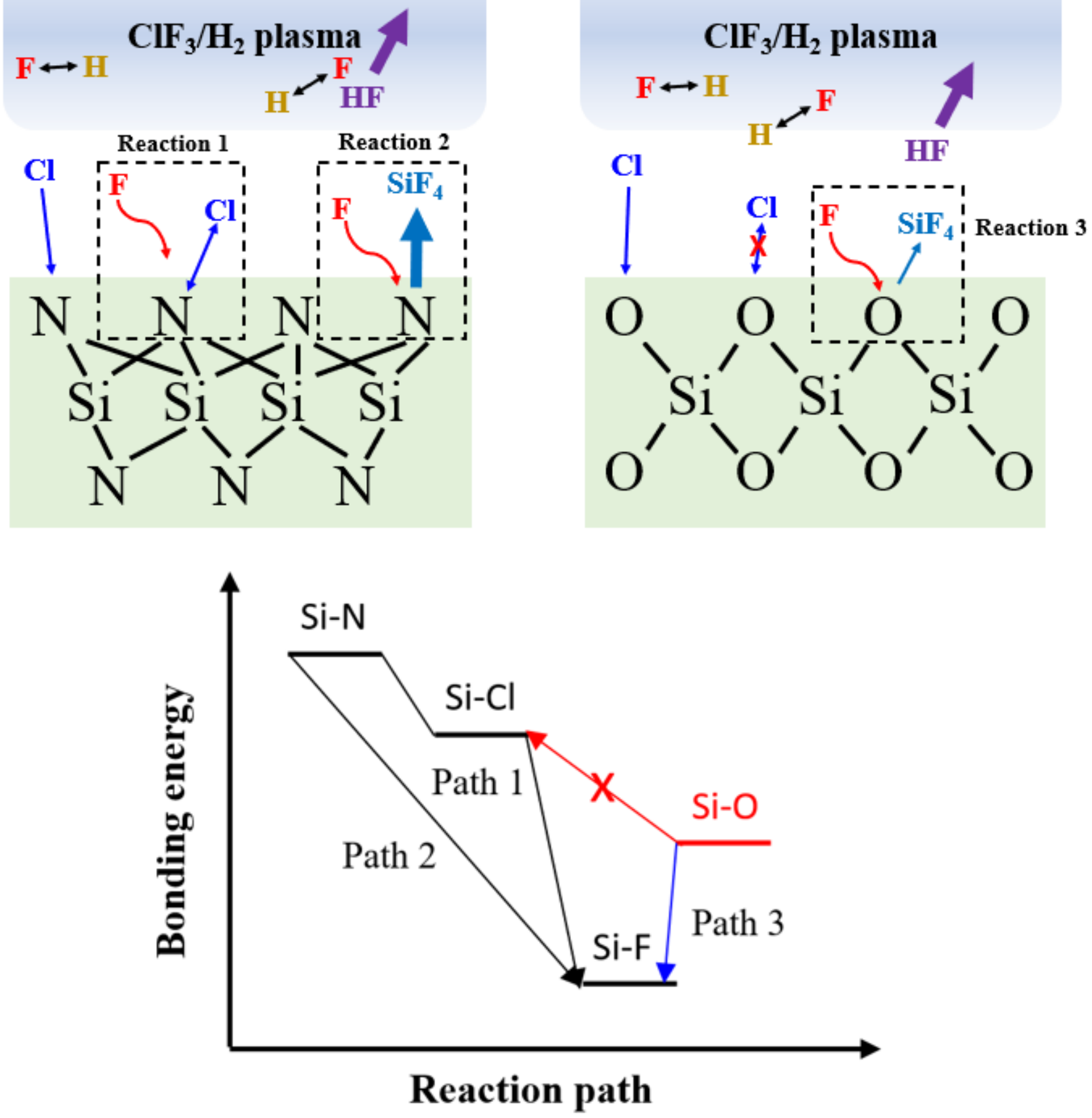

Figure 6

Schematic of chemical reaction of $\mathrm{ClF}_{3} / \mathrm{H}_{2}$ remote plasma on etching of $\mathrm{SiN}_{\mathrm{x}}$ and $\mathrm{SiO}_{\mathrm{y}}$. Possible reaction paths are illustrated. 

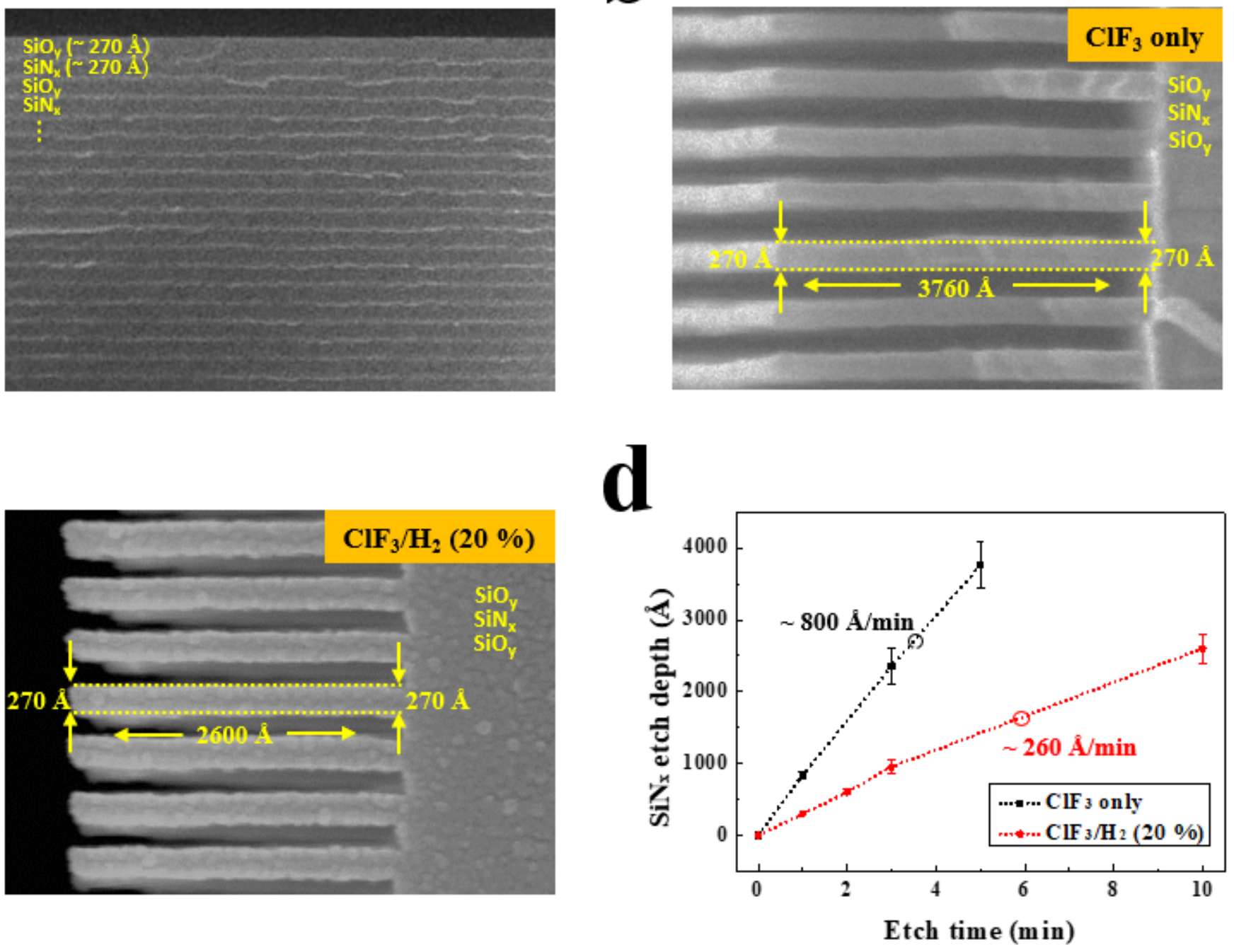

Figure 7

Etch characteristics of $\mathrm{ClF}_{3}$ only and $\mathrm{ClF}_{3} / \mathrm{H}_{2}(20 \%)$ plasma in stacked $\mathrm{SiN}_{\mathrm{x}} / \mathrm{SiO}$. a) SEM images of reference stacked $\mathrm{SiN}_{\mathrm{x}} / \mathrm{SiO}_{\mathrm{y}}$. Etch profile of stacked $\mathrm{SiN}_{\mathrm{x}} / \mathrm{SiO}_{\mathrm{y}}$ after the etching with b) $\mathrm{ClF}_{3}$ plasma and c) $\mathrm{ClF}_{3} / \mathrm{H}_{2}(20 \%)$ for 5 min and 10 min, respectively. d) Etch depth of $\mathrm{SiN}_{\mathrm{x}}$ in the stacked $\mathrm{SiN}_{\mathrm{x}} / \mathrm{SiO}_{\mathrm{y}}$ with etch time for $\mathrm{ClF}_{3}$ and $\mathrm{ClF}_{3} / \mathrm{H}_{2}(20 \%)$ plasmas.

\section{Supplementary Files}

This is a list of supplementary files associated with this preprint. Click to download.

- Supplementarylnformation.docx 